\title{
Case Studies in Social Death: The Criminalization and Dehumanization of Six Black and Latino Boys
}

\author{
Gabby Medina Falzone ${ }^{1}$ (1)
}

Accepted: 10 September 2021 / Published online: 28 September 2021

This is a U.S. government work and not under copyright protection in the U.S.; foreign copyright protection may apply 2021

\begin{abstract}
To fully grasp the systems of oppression youth of color must navigate, educators must consider their experiences outside as well as inside the classroom. This paper adds to the small but growing body of literature across fields highlighting how Black and Latinx youth are simultaneously positioned by schools and the justice system as criminals that must be contained and removed from school and society. This paper argues that the concept of social death, which refers to social suffering as a result of criminalization and dehumanization, helps contextualize the process by which carceral oppression manifests in students' lives. Based on an interview study with thirty adults who were first incarcerated as adolescents, this paper focuses on three Black and three Latino male participants' experiences with social death in schools and their neighborhoods.
\end{abstract}

Keywords Social death · Adolescence $\cdot$ Criminalization $\cdot$ Dehumanization $\cdot$ Juvenile justice $\cdot$ School-to-prison pipeline

\section{Introduction}

My crime was like, I don't even feel like I did no wrong.... I feel like that's how they get us though. It's little minor stuff that then turn into a felony. By the time you look around, you're in there for real. That's what happened to my homeboy. He got in like three fights at school, got three, five citations. It blew up from there, he was in jail for a year. He had all types of misdemeanors that they said led up to a felony. Like are you talking about murder and killing? You put somebody that's not even done no killing around killers.

Gabby Medina Falzone

gfalzone@csuchico.edu

1 College of Behavioral and Social Sciences, Chico State University, Chico, CA, USA 
The analysis above is from Wally, a young Black man who was 22 years old at the time of his interview, after he told me he was arrested for a fight at school when he was 14 years old, which lead to five days in juvenile hall. As an education scholar and former middle school teacher, I was familiar with experiences of Black students, like Wally and his classmate, in which police address school infractions through arrests and incarceration. What is less discussed in schools and in the field of education is how these students are treated by police outside of the classroom. Wally's first police interaction in his neighborhood from the same year illustrates how the treatment of 14-year-old Wally by teachers and police in school mirrored his treatment by police out of school.

Mother's Day was coming up and, not having money, Wally shoplifted a few watches for his mom and other women in his family. Someone saw him, and he ran and dropped the watches, but the police had already been called. When Wally saw the police car he lay on the grass and placed his hands out where the officer could see them. On the ground with his arms out, the officer still told Wally, "Don't move. I'm gonna shoot you." I asked him how, at 14 years old, he knew to lay down and put his hands out. He answered, "Because everybody getting shot like this. This is the time when Trayvon just got shot."1

To fully grasp the systems of oppression students of color must navigate requires contextualizing their experiences in and out of school. This paper adds to the small but growing body of literature across fields highlighting how Black and Latinx youth are simultaneously positioned by schools and the justice system as criminals that must be contained and removed from school and society. Using Wally's experiences, along with the experiences of two other Black men and three Latino men with surveillance, policing, and punishment during their adolescence, the paper provides insights into the overarching system of carceral oppression that manifests in schools and neighborhoods.

This paper argues that the concept of social death is useful metaphor for contextualizing participants' carceral experiences. Social death in general refers to ways Black and other oppressed populations have been and continue to be treated as outcasts and cast out from society. The iteration of social death used in this paper refers to social suffering that results from both criminalization and dehumanization. The paper first defines social death and then summarizes how social death and other forms of suffering played out in the lives of all the participants of a ground theory interview study, before centering the experiences of the six Black and Latino me, as exemplars of the ways criminalization and dehumanization reflected and reinforced social death during their adolescence.

\footnotetext{
${ }^{1}$ Trayvon Martin was a 17-year-old unarmed Florida high school student who was shot in 2012 as he walked home from 7-Eleven by George Zimmerman, who thought Trayvon looked suspicious (Weinstein \& MoJo Team, 2012). Zimmerman was charged and later acquitted of second-degree murder (Alvarez \& Buckley, 2012).
} 


\section{Social Death and the Nexus of Carceral Oppression}

The school-to-prison pipeline is perhaps the most ubiquitous research and policy metaphor describing the link between the school system and the juvenile justice system. $^{2}$ While the actual definition of the school-to-prison pipeline is nebulous (King et al., 2018; McGrew, 2016; Skiba et al., 2014), the pipeline can generally be summed up this way: the post-1980s moral panic based in the fear of dangerous youth criminals was soon followed by tough-on-crime laws and zero tolerance policies in schools, leading to high rates of suspensions and expulsions, especially for Black and Latino youth (Archer, 2009; Mallet, 2017; Noguera, 2003; Wun, 2016). Since there is high correlation between suspensions and expulsions, the non-completion of high school, and incarceration (Wald \& Losen, 2003, p. 11), the pipeline argument concludes that school suspensions and expulsion are a key causal impetus for youth incarceration (Heitzeg, 2009; Mallett, 2017).

This pipeline narrative often positions school and juvenile justice as separate or as unintentionally overlapping systems of criminalization, control, and punishment. For example, Skiba et al. (2014) conclude that there is a relationship between school discipline on one end of the pipeline and juvenile justice involvement on the other end, but fail to consider more systematic ways schools and juvenile justice might interconnect. Mallett (2017) does argue that there is an interconnection, stating that both "schools and juvenile courts" have "always had a focus on control of young people, particularly those difficult or troubling to manage" (p. 16), but then argues that they "never intended to operate in a collaborative paradigm" (p. 15, italics mine).

A small, but growing, group scholars challenge the premise that schools and jails are two ends of a trajectory, each with their own parallel, or unintentionally overlapping, social control structures. They instead see the school system and the justice system as a "nexus or a web of intertwined punitive threads" (Meiners, 2007) that are part of an overarching system of criminalization and punishment targeting youth of color and low-income youth (Fasching-Varner et al., 2014; Meiners, 2007; Meiners \& Winn, 2014; Rios, 2011; Rios \& Vigil, 2017; Shedd, 2015; Sojoyner, 2013, 2016; Wun, 2016). Rios (2011) conceptualizes a youth control complex, which is "a combined effect of a web of institutions" including, but not limited to, schools and the juvenile justice system, that use material and symbolic means ${ }^{3}$ to "collectively punish, stigmatize, monitor, and criminalize young people in an attempt to control them" (p. 40). The net effect of this youth control complex is hypercriminalization, which Rios (2011) defines as "the process by which an individual's everyday

\footnotetext{
2 As of December 2015, "there have been at least 7 special journal issues and 50 symposia on the topic. At least 16 books, 13 dissertation theses, and 145 articles, conference papers, reports, or book chapters contain 'school-to-prison-pipeline' in the title. The term appears in the text of at least 294 academic journal articles, 876 news stories, and 263 books. Google Scholar finds the term in 3,200 sources while Google finds the term in 324,000 sources" (McGrew, 2016, p. 341-2).

3 "Material criminalization" refers to tangible behaviors such as "police harassment" and "incarceration" while "symbolic criminalization" refers to intangible behaviors such "surveillance" and "profiling" (Rios, 2011, p. 40).
} 
behaviors and styles become ubiquitously treated as deviant, risky, threatening, or criminal, across social contexts" (p. xiv).

Hypercriminalized youth are "always and already scrutinized and under systems of surveillance" (Meiners, 2007, p. 14, italics in original) and "simultaneously construed and constructed as dangerous, uneducable public enemies" (Meiners, 2007, p. 7) in and out of schools, regardless of their actual behavior. This preemptive and perpetual criminalization is only one aspect of their experience; hypercriminalized youth are simultaneously dehumanized. To those labeling youth as criminal, these youth appear human but are "really subhuman on the "inside"" (Merlo \& Benekos, 2017, p. 27; see also Haslam \& Loughnan, 2014), unworthy of due process or being treated as a youth (Davis, 2015; Ferguson, 2000; Wun, 2016) and only worthy containment or removal from school and society (Rios, 2011, 2017). While Black youth are most often categorized as dangerous and disposable in this way (Goff et al., 2014), Latino youth also experience similar criminalization and dehumanization (Rios \& Galicia, 2014; The Sentencing Project, 2017). ${ }^{4}$

Social death is a helpful way to conceptualize this nexus of carceral oppression that Black and Latino boys must navigate, both the preemptive and perpetual criminalization and dehumanization and the containment and removal that results from that criminalization and dehumanization. The socially dead are outcasts and cast out of society, stripped of the right to be treated as part of the group and part of humanity.

Social death was initially used to refer to social violences of slavery. Patterson (1982), who coined the term, used it to refer to the way how some enslaved populations across cultures and across time, such as Africans in the Americas, were deemed "social nonpersons" (p. 40) either as "someone who did not belong because he is an outsider" or "someone who became an outsider because he did not (or no longer) belonged" (p. 44). Afropessimist scholars such as Sexton (2010, 2016) use social death to describe lingering social violences of slavery inflicted on African Americans today, namely anti-Blackness labeling and treatment as less than human.

Just as the concept of abolition originally focused on abolishing African slavery and then was later adapted by those wanting to abolish the carceral system, social death originally described the social violences of African slavery and was later adapted to describe the social violences of carcerality. Sowle (1993) uses social death to describe the rise of US penitentiaries in the 1930s as a way to socially isolate criminals who "were germs infecting the body politic" (p. 528). Guenther (2013) discusses social death in terms of solitary confinement, in which incarcerated individuals are forcibly separated from human connection. Price (2015) also argues that "to be sentenced to prison is to be sentenced to social death," though in addition to the mistreatment in prison he adds the lingering stigma of incarceration after release (p. 5). Rios (2011) briefly mentions this iteration of social death referring to six of his participants who ended up in prison, along with the "social incapacitation" or "microdoses of social death" that prevented all his participants "from functioning,

\footnotetext{
4 Proportionately, Black and Native youth experience the highest rates of racial disparities in the juvenile justice system; however, by the numbers, it is Black and Latino boys (see for example Rovner, 2016).
} 
thriving, and feeling a sense of dignity in their daily interactions with institutional forces" (p. 160).

Cacho's (2012) iteration of social death shifts the focus from incarceration and post-incarceration to a focus on apriori criminalization. She uses her concept of social death to conceptualize the violences of labeling, surveillance, and punishment of gang members, undocumented immigrants, and suspected terrorists. In her version of social death, an individual's everyday behavior is criminalized, not because the individual is acting like a criminal, but because, by their very existence, they are criminal. She further argues that criminalization is one aspect of social death; of equal importance is how certain groups of people are categorized as "illegible for personhood" and unworthy of empathy or compassion (Cacho, 2012, p. 6), in other words dehumanized, which she defines as relegation to a status of "living death" and "dead-to-others" (p. 7).

Cacho's (2012) definition of social death best fits the criminalization and dehumanization Wally and the other five participants highlighted in this paper experienced from teachers and police during their adolescence. In her version of social death, criminalization is conflated with criminality, where rather than labeling someone a criminal for committing an offense, certain marginalized groups are treated as if they are "certain to commit future crimes and may well have already committed crimes unwitnessed", what she calls a "de facto status crime" (Cacho, 2012, p. 43). ${ }^{5}$ The simultaneous dehumanization of youth who are preemptively and perpetually criminalized justifies the "punitive and harsh retaliations and reprisals" (Merlo \& Benekos, 2017, p. 27) that remove youth from schools and their neighborhoods (see for example Ferguson, 2000; Goff et al., 2014; Jones, 2014; Rios, 2011).

To contextualize the findings from the six participants, I will first describe the larger interview study that these six case studies originate from, including the theoretical framework derived from the overall interview study data.

\section{Grounded Theory and Faces of Death}

The six cases studies highlighted in this paper are drawn from an in-depth interview study conducted between June 2016 and June 2019 with 30 adults who were first incarcerated before age 19. Using a grounded theory approach (Charmaz, 1996; Corbin \& Strauss, 1990; Strauss \& Corbin, 1998), the purpose of the study was to gain a better understanding of the phenomenon of juvenile incarceration from those who had firsthand experience. Participants comprised a demographically varied group, who ranged in age from 18 to 76; ranged in gender from male, to female, to genderqueer; ranged geographically from rural, to suburban, to urban areas; and who identify across a range of racial/ethnic groups, including, but not limited to, Black, White, Latinx, Asian, and Native American. All participants lived in California at the time of their interviews, and many were incarcerated in California, though

\footnotetext{
5 Story (2016) differentiates between the two by arguing "criminality is understood to be a state of objective deviance located in the individual", while "to be criminalized is to be subjectified as well as subjugated by the coercions of law enforcement and the criminal justice system" (p. 266).
} 
a few were incarcerated in other states. Of the thirty participants, I knew eighteen of them prior to the project, I recruited five through flyers, and seven were referred to me by friends and colleagues.

Interviews were semi-structured, giving participants the freedom to discuss anything they thought was important related to their experiences before, during, and after juvenile incarceration. Participants were then given the option to review, revise, and analyze their own initial interviews, as well as participate in follow up interviews. In the end, twenty participants reviewed, revised, and analyzed their interviews, fifteen participated in follow up interview, and one participated in two follow up interviews. Interview data was coded using MaxQDA qualitative software with help from a team of justice-impacted undergraduate students.

In grounded theory, the theoretical framework is derived from the data. Most of the interview data focused on suffering during adolescence, predominately the suffering inflicted by teachers, police, foster care staff, and carceral staff on participants in and out of school, and the suffering participants felt resulted from the way they were treated. I used data from the interview study, as well as data from a 16-month ethnography of a boys' detention center in Northern California conducted between October 2012 and June 2014, to develop an ecological framework to conceptualize this suffering. I call this theoretical framework the three Faces of Death, where death is a metaphor for suffering. There were three iterations of suffering, which I call social, psychological, and biological death.

I adapted Cacho's (2012) iteration of social death to conceptualize the violences of criminalization and dehumanization that led to social suffering in the form of incarceration, psychiatric hospitalization, suspension, expulsion, being held at gunpoint by police, and in other ways in which they were treated as if they did not deserve to be a part of society. Unlike social death, which came from an existing tradition, the other two forms of death are new terms. I use psychological death to refer to the psychological suffering associated with social death, for example, the internalization of criminal or failure labels, feelings of powerlessness, frustration, and hopelessness, and mental illness diganoses such as depression, anxiety, and posttraumatic stress syndrome (PTSD). I use biological death to refer to physical health problems associated with social and psychological death, including the actual loss of life, which, unfortunately, one of the study participants succumbed to a month after his interview and two months after his $25^{\text {th }}$ birthday (Falzone, 2020).

The interviews (as well as the ethnographic data) tell many stories of suffering due to criminalization and dehumanization within and across the social, psychological, and biological domains. This paper focuses on one domain of death, that of social death, and specifically the experiences of six Black and Latino men with social death during their adolescence. In the larger interview study social death manifested in a variety of ways that could often be categorized along racioethnic and gender lines; for example, the ciswomen of any racioethnic background and the white male participants were more likely to be labeled as mentally ill and subsequently involuntarily hospitalized after arrest as adolescents. I chose to highlight the story of these six Black and Latino male participants, after I was struck by how similar their racialized experiences with criminalization and dehumanization were 
to each other and how powerfully these experiences exemplify the nexus of carceral oppression that manifests in both schools and neighborhoods.

The three Black male participants were: Wally, age 22; Hightower, age 47, and Tio, age 18. Tio and Hightower identified as African American, and Wally identified as Jamaican. The three Latino participants were: Michael, age 22; Benito, age 26; and Shorty, age 30. All three Latino participants identified as Mexican. Benito was undocumented, coming to the United States when he was six months old. All six participants grew up in urban, low-income neighborhoods of color. Five participants spent all or the majority of their lives in California, while Wally spent his elementary school years in Florida and moved to a foster care home in California when he was in high school. I knew four of the six participants prior to the study. Of the six, Hightower and Benito participated in a follow up interview. All six were given a copy of this paper prior to publication to ensure that it accurately described their experiences.

\section{Manifestations of Social Death}

Social death is the social suffering that results from both criminalization and dehumanization. Teachers and police criminalized and dehumanized Wally, Benito, Tio, Shorty, Michael, and Hightower in and out of school leading to three manifestations of social death. In the first example, Benito and Michael share some of their experiences with escalating criminalizing and dehumanizing treatment from troublemakers to gang members. In the second, Shorty and Tio share their experiences with being criminalized and dehumanized as gang members from the start. In the last example, we revisit Wally's experience he shared at the start of this paper with being held at gunpoint, and Michael and Hightower share their experiences being criminalized and dehumanized as dangerous criminals.

\section{Escalating Death}

In social death youth are treated as if, due to their inherent criminal nature, they may at any time commit or have already committed a crime. Thus, proactive policing tactics such as surveillance and searches at any place and any time become justified tools for the school and juvenile justice system to thwart or punish a crime (Davis, 2015; Jones, 2014; Fine et al., 2003; Kupchik, 2010; NASEM, 2018; Rios, 2011; Wun, 2016). School officials and police labeled many of the Latinx participants of the larger interview study as gang members. This finding corresponds to other scholarly work that shows how California Latinx youth "are targeted and more likely to be defined as gang members" that youth of other racioethnic backgrounds (Gonzalez \& Portillos, 2007, p. 260). This section highlights a few of Benito's and Michael's similar experiences with surveillance, searches, and removal. In their early adolescence school officials and police labeled Benito and Michael as troublemakers, however by seventh grade they 
labeled both boys as gang members and escalated their surveillance, searches, and punishments.

Benito, who identifies as Mexican, went to the same school from pre-K to sixth grade and had never been in trouble until sixth grade when he started being treated differently by school officials. The first time Benito got in trouble, he was suspended from school for calling a girl in his class a "ho." He "had [just] been elected the school president" but "ended up getting kicked out of that position" because of the suspension. By seventh grade, school officials suspected Benito was a gang member and surveilled and searched him on a regular basis.

Benito shared one of his experiences when he 12 years old in the new school he started after being expelled from the previous one. On this day, school staff thought they smelled marijuana and "then they called me into the office" and, without a parent present, they searched him. Even though he did not have any drugs on him, the school still "called the cops" and he was arrested. In another incident in seventh grade, Benito was "called into the office by the campus police officer" who accused him of "tagging", that is, writing his graffiti name on school property. Again, without calling his mother, the officer began questioning him, telling him that "someone already told us it was you, just admit to it and you'll be in less trouble." Believing the officer, he admitted he was the one who had tagged the school property. He was promptly expelled.

Michael's early experiences with surveillance, search, and removal in school were often starkly similar to Benito's. In the beginning Michael was also labeled a troublemaker. Michael, who identifies as Mexican, shared an experience he had in sixth grade when principal accused Michael of stealing her car keys. Since he was being sent to her office often, she reasoned that any "bad" things that happened were caused by him. She threatened to call the police on him unless he admitted the theft. As it turned out, she found her car keys and apologized. Michael told me the key incident was one of the few times he remembered not being punished at school for something he was accused of and did not do.

Just like Benito, things changed by seventh grade when he was labeled a suspected gang member. In one example, Michael was pulled off the school bus on his way home. The school security officers searched his backpack for drugs but did not find any. They then searched his clothes and found a tiny arrowhead, which they thought he must have used to carve his "tag" on one of the desks in the biology room. They then arrested him for the tagging, and he was put on house arrest for a month.

Benito and Michael's escalating criminalization as gang members in school was mirrored by their experiences with police in their neighborhood, though the escalation was more severe in Michael's case, whose experiences are shared in The Dangerously Dead section. The rest of this section centers Benito's escalation with police and the juvenile courts. One night when Benito was 13 years old, he was stopped by police for riding his bicycle late at night. The police told him, "You look like you've got something. We're going to search you." They patted him down and found a butterfly knife, which is misdemeanor in California (Cal Pen Code $\S 17235$; Cal Pen Code $\S 21510$ ). While they did not take him to juvenile hall, they did cite him. When he went to court, the judge adjudicated him to probation and, because he 
had a blue bandana in his pocket at the time of arrest, labeled him a gang member and added "gang terms" to his probation.

The criminalization escalated soon after his adjudication, when the police came to search his "area" of the house to uncover evidence of gang activity. ${ }^{6}$ They found "found blue shirts and things that I wasn't supposed to have" due to the gang enhancement on his probation, including a "book by Sanyika Shakur, called The Autobiography of L.A. Gang Member" and either the movie "American Me or Blood In and Blood Out." Believing they found the proof of gang affiliation they needed, the police arrested him on a probation violation, and he was put on "intensive probation with gang terms, because, I was like an affiliate of, or at least they had defined me, to be a certain gang member."

By the time they were both twelve years old, school officials and police labeled Benito and Michael as gang members, justifying an escalation in surveillance, searches, and punishments. In social death gang members, actual or suspected, are stripped of their right to be treated as minors and their right to due process, such as innocent until proven guilty of committing an offense. To be criminalized as a gang member means that their behavior, from Benito tagging his name and Michael carrying an arrowhead which might have been used to tag is name to Benito riding his bicycle at night, implied something inherently gang related.

\section{Dead from the Start}

Cacho (2012) argues that the gang member is criminalized in a way that "forecloses empathy" (p. 82) "beyond even unsympathetically begrudged ethical obligations" (ibid, p. 64). While Benito and Michael experienced an escalation over the course of a few years of their criminalization as gang members and the ensuing punishment, other interview participants were criminalized as gang members from the start. This section highlights the experiences of Tio and Shorty who school officials and police labeled as gang members, in Tio's case from the first time he got in trouble, and for Shorty, when no offense had been committed.

The first time Tio, who identifies as African American, got in trouble at school, he was arrested. He was in sixth grade and 11 years old. Another student stole a teacher's laptop and used Tio's locker to hide both the laptop and a gun. School officials could see on camera that Tio was not the one who placed the items in the locker, but since Tio's locker was used, school officials told him that he must have been involved. No matter how much Tio denied knowing about the incident, the school called the police who arrested him. The police did not arrest the student who placed the items in the locker.

Despite Tio only being 11 years old, the school did not call Tio's mother while he was being questioned at the school nor when he was arrested and sent to juvenile hall. When I asked him why he thought they did not believe him and why he was arrested, he answered that "they thought I was connected to a gang because

\footnotetext{
${ }^{6}$ Benito grew up in a small apartment with other families and never had his own room, only a small area in a room.
} 
there was a gun." His arrest and incarceration were dehumanizing. Describing his 11-year-old self, he told me, "I'm freaking out.... They come in and they're like, 'please put your hands behind your back, please be silent' and stuff like that. Then I go to juvenile hall, like I'm a convict, I'm crying my eyes out."

Social death does not start and end with an individual youth; the veil of death also shrouds the families and neighborhoods of the socially dead. Shorty shared two experiences in which police treated both his mother and his neighborhood as inherently criminal. When Shorty was 12 years old:

The local police did a huge sweep in the neighborhood. They went to the middle school and the high school, and they took all the Latino children from [his specific neighborhood] out and they lined us up in the office with gang task force and started taking our photos.

The police used the photos to create a county-wide gang database. None of the boys had committed an offense and there was no proof any were gang-involved. When Shorty's mother and other mothers from the neighborhood found out what had happened to their children, they sued the police, but in the two years their lawsuit dragged through the courts, the damage was already done; the school and the police started treated all the youth from that neighborhood as if they were dangerous gang members.

Once in the gang database, Shorty experienced the constant surveillance and searches that come with being labeled a potential and perpetual criminal. The searches were not limited to his person. With pain in his voice, Shorty told me about a time he was pulled over by the police when he was in the car with his mom. The officer handcuffed both him and his mother and started going through their car. He told me the officer:

had the nerve to say, 'you [neighborhood] moms are constantly protecting your kids and carrying their drugs, carrying their weapons. I know your kind. I'm going to go through your entire car.' [The officer then] ripped up the car, went through everything. They didn't find anything. That hurt me [to have my mom treated that way]. After that, there wasn't an apology. She just took off the cuffs, left everything a mess, and said, 'Well, we'll catch you another time.'

By the time he was arrested at 16 years old for guilt-by-perceived association, Shorty had already been carrying the preemptive gang label for four years. Shorty explained the guilt-by-perceived-association incident that led to a six-year sentence. He and a friend were arrested at a party where someone was stabbed. The police who arrested them told the boys, "We know you didn't do it, but we know you know who did." The police did not have any proof that the two boys had witnessed the stabbing but were convinced they and the stabbing were gang-affiliated, and thus the boys were affiliated in some way with whoever had committed the crime. Shorty knew that he had not done anything and thought the court system would clear his name. He quickly realized that being innocent was not going to save him. Fearing a worse fate if they went through trial, both Shorty and his friend were pressured to take six years in prison as a plea deal. 
Similar to Benito and Michael, school officials and police labeled Tio and Shorty as gang members; unlike the first two participants, they never had the opportunity of being treated as troublemakers before being vilified as gang members. The school and police assumed Tio's gang membership through guilt-by-association from another student's possession of stolen property and a gun, while police preemptively labeled Shorty through guilt-by-association of his neighborhood. In both instances, there was no space for the boys to prove innocence or to be treated as young adolescent boys.

\section{The Dangerously Dead}

The dehumanization of the socially dead means that the accused forfeits their right to be treated not only as a minor but as overall as a human. For example, the inherent association of Blackness with criminality (Anderson, 2012; Wun, 2016) and nonpersonhood (Goff et al., 2014; Patterson, 1982; Sexton, 2016) makes it no surprise that Black youth are more likely to be shot by the police than any other racial group (Males, 2014). Wally, Michael, and Hightower all experienced dehumanization connected to being labeled dangerous. This section briefly revisits Wally's experience which opened this paper, before continuing Michael's escalating experiences with dehumanization as a gang member. This section ends with the experiences of Hightower, whose first and only experience with the justice system as an adolescent led to his imprisonment for a crime he did not commit.

In comparison to Benito and Michael whose criminalization by school police and police escalated over the course of a few years and Tio and Shorty who were extensively criminalized from the start, the degree of Wally's criminalization in school and that in the neighborhood contrasted sharply. Wally, who identifies as Black, was over six feet tall and 300 pounds at the time of our interview and already tall and husky by the time he was 14 years old. While he was arrested and jailed for five days for his first fight at school, his criminalization did not escalate to the level of his friend who had felony conviction for fighting. Wally credits this to the fact that he played football; he felt that while school officials did see Blackness, his height, and his girth as potentially dangerous, that label co-existed with a positive image of an athlete. The police officer who threatened to shoot Wally while he was on the ground did not have this this image of Wally the high school football star and merely saw Wally as a dangerous threat.

Wally was not the only of the six participants to share being confronted by armed police. Michael, discussed in the first section, shared how his criminalization and dehumanization had escalated by the time he was 16 years old and in $11^{\text {th }}$ grade. Michael recounted an experience that ocurred one day when he was "ditching" school to watch a basketball game

I was in my living room watching TV. Something just tells me to turn my head a little bit and I turned my head and I just see two cops walking [up to the door]. And the way they were dressed, they had on like armor. It looked like a movie. I'm looking and two of them have M-16s, and I see three more come up. And then those three have M-16s too. They're all dressed the same and 
I'm like, 'wait, what's going on?' And then after that, after the five passed by, there's two more. In the middle is the gang unit.

Michael thought about running but realized he would not get far, so instead he answered the door. One of the officers told him they had a warrant for his arrest. When Michael asked what it was for, an officer answered, "for not going to school." When I asked him why the police would show up with M16s because he was truant, he answered,

because they had put me on gang file... And at that time I wasn't even involved with a gang or nothing -that whole time I was getting arrested, from maybe 12 almost like to 16 [I wasn't in a gang]. I probably didn't start getting involved with the gangs until like my senior year. ${ }^{7}$

For Hightower being positioned as dangerous did not lead to an armed police response but it did lead to him to being incarcerated in a youth jail for violent offenders. The first and only time Hightower, who identifies as African American, was stopped by police, he was 15 years old. He was stopped by the county sheriff for riding his bicycle home from his friend's house past curfew. The sheriffs "asked me if that was my bike and I said, 'this is my bike." Then, without parent consent, he was taken "to the station and they took pictures of me, and I remember being fingerprinted" before being driven home. A few months later two detectives came to his house to say that on the evening he had been picked up, there had been a violent robbery at a beauty salon. Without telling him at the time, he had been stopped and taken to the police station because he "fit the description" of the police sketch. It did not matter to the police that Hightower could not see without his glasses and the sketch had no glasses. Despite having no police record, not matching the sketch, and his friend saying Hightower had been at his house, he was arrested for the robbery.

Terrified, but sure that the courts would see he was innocent, Hightower, unlike Shorty, went to trial. However, like Shorty, no one seemed interested in his innocence. The dehumanization of social death for Hightower manifested not in being held at gunpoint but in the violence of being "dead to others"; he existed as a criminal and not a person with rights, leaving him no recourse in a court of law. His public defender advised him to plead guilty or run the risk of being sentenced as an adult rather than a juvenile. He took the plea and was sentenced to two years in a detention facility for violent offenders for a crime he did not commit.

Police positioned Wally, Michael and Hightower as dangerous criminals and then criminalized and dehumanized them as such: rather than a kid scared that he was caught shoplifting, police positioned Wally as a danger even when he was on the ground with his hands up; rather than a teen ditching school, police positioned Michael as a gang member whose truancy implied something more nefarious; and rather than a teen breaking curfew, police positioned Hightower as a criminal who used his bicycle to commit a violent crime. As potential and perpetual dangerous

\footnotetext{
${ }^{7}$ Michael then told me that the repeated accusations of being in a gang, in part pushed him to eventually join a gang. This internalization of labels was a key theme of psychological death.
} 
criminals, no proof of a dangerousness was needed. As less than human, no humaneness was needed in their treatment.

\section{Corroborating Death}

If schools and the juvenile system historically reflect and perpetuate larger forces of oppression, including an overarching system of criminalization and punishment targeting youth of color and low-income youth, what does this overarching system entail and how does it relate to the six participants' experiences with social death? This section uses others' empirical finding and California law to contextualize some of the structural forces implicated in the participants' treatment. In loco parentis and California gang laws codify forfeiture of rights for the socially dead into law while the contagion effect describes the ways social death expands beyond the labeling and treatment of youth to include their families and neighborhoods. This section ends with a summary of the findings and the some of the limitations of the paper.

\section{In Loco Parentis}

In every story the six participants shared with me, parents and guardians were never called before or during a search or arrest. Part of this is due to the nature of social death itself: to be treated as less than human also means one is not perceived as a child. For example, Goff et al (2014) found that police officers were more likely to view Black children over age 10 as inherently less innocent than White children and were more likely to use force if they already had an implicit bias towards dehumanizing African Americans. They also found that officers overestimated the ages of Black and Latino children. In the eyes of others, Tio is not a terrified and crying 11-year-old, but a "criminal in being" (Cacho, 2012, p. 66) who deserves his fate (ibid, p. 88-89). Adultification and dehumanization of Black and Latinx youth are not the only explanations for not calling their families; another is the concept is in loco parentis.

A common legal justification for warrantless searches and disciplinary action without parent permission in and out of school is the concept of in loco parentis. In loco parentis, which in Latin means "in place of parents", relates back to English common law, giving schools (Dutton, 1984) and the juvenile justice system (Platt, 1977) the power to act in place of parents. ${ }^{8}$ In loco parentis manifests as the paternal authority of the state to compensate for parents' inability to monitor their children and their failure at teaching their children self-control and proper socialization (Gottfredson, 2001; Krisberg \& Austin, 1993; Meiners, 2007; Platt, 1977).

In loco parentis is enacted by school officials (Davis, 2015) and juvenile justice officials (Benekos \& Merlo, 2014) to circumvent the constitutional right against

\footnotetext{
${ }^{8}$ In New Jersey v. T.L.O in 1985, the Supreme Court ruled against the letter of in loco parentis but held to the spirit of the concept in deciding that "primary and secondary school officials could search students without a warrant and with only reasonable suspicion of a school rule or criminal law violation" (GuptaKagan, 2018, p. 2015).
} 
unreasonable search and seizure. Since the socially dead are treated as inherent criminals regardless of their actual behavior, no reasonable standard proof of an offense is needed for searching Benito and Michael at school and Benito and Hightower in the neighborhood. For youth on probation, warrantless searches are codified into law. For example, California law requires "that the minor be subject to warrantless searches of his or her person, residence, or property under his or her control, upon the request of a probation officer or peace officer" (Cal Wel \& Inst Code $\S$ 794). This is the law that allowed Benito's "area" in his home to be searched as well as Shorty's mother's car.

In loco parentis can also explain why parents were not consulted after a search or arrest. When Shorty and all the boys from his neighborhood were illegally lined up and photographed for the gang database, the mothers only found out after the boys told them. The mothers then had to sue the police to regain the right to have a say in what happened to their children. After Hightower's arrest, his mother was relegated to the sidelines of the court proceedings. For example, rather than help explain the law to her to help her and Hightower figure out how to fight for his innocence, the public defender put pressure on Hightower to plead guilty.

\section{Legal Death}

In loco parentis is not the only violation of due process codified into California law. Two anti-gang laws, one enacted at the start of the moral panic in the 1988 and one as the moral panic began to wane in 2000 , were used against many of the participants both in the spirit and the rule of the laws. ${ }^{9}$ Benito told me that school officials associated tagging with gangs, and believed he was punished harshly for his minor offense due to his perceived gang membership. His claim is corroborated by other research which show that tagging, though an infraction (Cal Pen Code $\S$ 640.5) or misdemeanor (Cal Pen Code $\S 594$ ), can be considered a felony under the California Street Terrorism Enforcement and Prevention (STEP) Act (Cal Pen Code Pt. 1, Title 7, Ch. 11) if thought to be committed by a real or perceived gang member (see for example Bloch, 2019).

The original STEP Act of 1988 defines a "criminal street gang" as.

any ongoing organization, association, or group of three or more persons, whether formal or informal, having as one of its primary activities the commission of one or more of the criminal acts [mentioned in a previous section], having a common name or common identifying sign or symbol, and whose members individually or collectively engage in, or have engaged in, a pattern of criminal gang activity. ${ }^{10}$

\footnotetext{
9 The moral panic of the late 1980s to the early 2000s, also called the tough-on-crime era, resulted in many of the punitive laws and policies against urban Black and Latinx youth. Policy makers, teachers, and police saw these punitive policies as the most effective way to combat youth crime in both criminalized neighborhoods and the schools in those criminalized neighborhoods (Farmer, 2014).

10 The justification for this sweeping legislation is included in the act which states "The State of California is in a state of crisis which has been caused by violent street gangs whose members threaten, terrorize, and commit a multitude of crimes against the peaceful citizens of their neighborhoods" (Cal Pen Code Pt. 1, Title 7, Ch. 11).
} 
Anyone deemed to be a member of a gang in the commission of a crime was subject to enhanced punishment. This broad definition of criminal gang was broadened even more in 2000, when California's Proposition 21 amended the STEP Act and "changed the definition of gang affiliation from "active participation" in a gang to anyone who "benefits from" the actions of a gang.... offenders no longer needed to be members of a gang to be charged as active gang members" (Cacho, 2012, p. 45). ${ }^{11}$

For Benito's gang enhancement on his probation and Shorty's six-year prison sentence, the justice system did not need proof that they were in a gang. They did however need to prove that both boys were affiliated with a gang and that Benito carrying an illegal knife and the stabbing at the party Shorty attended were crimes "committed for the benefit of, at the direction of, or in association with a criminal street gang" (Estevane, 2105, p. 223). However, in the logic of social death, Benito and Shorty were denied the possibility of innocence before being proven guilty. Benito's and Shorty's Proposition 21-enhanced surveillance and punishments were not unique; for example, Rios' (2011) participants were so impacted by Proposition 21 they started to use "Prop 21 as a verb" (p. 33).

While Benito and Shorty were the only two participants who stated they received punishment enhancements based on the STEP Act, Michael and Tio experienced death in the spirit of the law. Tio felt the school and the police assumed he must have been in a gang for the laptop and the gun to end up in his locker, justifying his arrest and incarceration at 11 years old. For Michael, the extralegal enhanced surveillance of the anti-gang taskforce armed with assault-rifles that responded to his truancy was justified on his perceived gang affiliation.

\section{Racialized and Spatialized Death}

Shorty's experiences show some of the ways in which social death through in loco parentis is racialized and spatialized, translating into a loss of rights for the socially dead youth that then extends to those around them. In loco parentis is based on a belief that criminalized youth are not only inherently criminal but that they, are at least in part, criminal due to the inherent criminal nature of their families. This is exemplified in the way the police office addressed Shorty's mother during the traffic stop. However social death is linked "not only to the body of the family and its ancestors but also to the segregated spaces where impoverished people of color live" (Cacho, 2012, p. 72). In his socially dead neighborhood made up of socially dead urban poor Latino families, surveillance and proactive policing were used justify the preemptive neighborhood gang database. These tactics stem from beliefs that

\footnotetext{
11 Even though juvenile crime rates had fallen since their height in early 1990s (Scott \& Steinberg, 2008, p. 105), fear of the dangerous gang member gripped the public and the initiative passed with $62 \%$ of the vote.
} 
criminality may be "transmitted spatially" (Cacho, 2012, p. 72) requiring prevention and containment of the "contagion effects of a socially dysfunctional neighborhood" (Story, 2016, p. 264). Shorty's experience is not unique. Other scholars such as Rios (2011) and Vaught (2017) also found data that corroborate this contagion effect.

This contagion effect can help make sense of the reasons why schools many of the participants attended had police on campus and were so focused on surveillance and searches. Through the lens of social death, de facto crime neighborhoods need schools that focus on surveillance and control (Gottfredson, 2001). These schools begin to reflect "institutions of confinement" in themselves with a "primary mission...not to educate but to ensure "custody and control" (Wacquant, 2001, p. 108, italics in original) by "ratchet[ing] up their punishment policies" and their use of "security forces... and surveillance technologies" (Kupchik, 2010, p. 13-14). Shedd (2015) calls this a "school disciplinary superstructure" (p. 81) which surveils and disciplines youth of color in schools in ways reflected in the surveillance and discipline in the surrounding neighborhoods.

Shorty experience is strong example of this racialized and spatialized contagion effect. In the larger interview study there is other weaker evidence, though still evidence, that the contagion effect increased students' risk of being criminalized in school. For example, Hightower was the only of the six participants who went to school in a mostly middle-class white neighborhood. He was also the only one of the six and one of few of the 30 interview participants who did not experience social death in school. There is not enough data to make a causal connection that his avoidance death in school is due to the lack of the contagion effect. Hightower did mention that his arrest occurred in this neighborhood and felt he was singled out by police that night, since he was one of the few Black youth who lived there.

\section{Summary of Death}

Rather than a pipeline from school to prison, the six participants navigated a nexus of carceral oppression in and out of school during their adolescence. The dual forces of criminalization and dehumanization created social suffering through the bombardment of ideological and tangible violences that came from being treated as inherently criminal and unworthy of being treated as human. The adolescent experiences of Wally, Benito, Tio, Shorty, Michael, and Hightower's in school and in their neighborhoods were steeped in social death as school officials and police systematically denied them their rights to be treated as children and their right due process that resulted in unwarranted surveillance, searches, and harsh punishments. There were overlaps and differences in how the six participants were treated as boys: Benito and Michael experienced an escalating progression in their criminalization and dehumanization from troublemakers at the beginning of middle school to suspected gang members by the end. Tio, Shorty, Wally, and Hightower were criminalized and dehumanized from the start, Tio and Shorty as suspected gang members, and Wally and Hightower as dangerous criminals. Despite some of the differences, all of the participants experienced social suffering as youth that lingers today. 


\section{Limitations}

While there are benefits of zeroing in on a subset of a larger study for a paper, such as the ability to highlight the richness of their particular experiences, this approach is not without its limitations. Unlike the ethnography, in which I was able to witness acts of criminalization and dehumanization and follow up with all parties involved to get their perspectives on incidents, I did not witness the interview participants' experiences and was not able to interview the teachers or police that searched, suspended, expelled, arrested participants, and held one at gunpoint, thus I cannot verify how they perceived of the participants. And while the experiences of the participants are corroborated, when possible, with others' empirical findings, with such a small sample size it is impossible to generalize these six experiences to speak of Black and Latino boys in California as a whole. Moreover, focusing only on boys omits the experiences of trans and cisgirls, as well as non-binary and other gender nonconforming youth who are, more often than not, erased from the conversation; while focusing only on Black and Latino youth omits the experiences of other youth that are disproportionately criminalized, such as Native Americans, Southeast Asians, and Pacific Islanders and consistently erased from the conversation or who, if are mentioned, are aggregated as "other" in juvenile justice and education data sets.

\section{Germination: Resurrecting the Dead}

Rather than a conclusion, this paper ends with a germination, a planting of a seed for change. While suffering was both the key theme of the overall interview study and of the six participants, to only focus on the misery of suffering paints a bleak picture with seemingly no hope for change. This tone of hopelessness is compounded by the explicit decision to not share examples of participants' agency, not because participants were helpless victims of circumstance, but because too often the rhetoric of grit and resilience inadvertently puts the onus for change on the oppressed rather than the oppressors. Since the future, nor even the present, need be filled with suffering caused by the criminalization and dehumanization of young people, this paper ends with some final thoughts on "imagining something different" from the nexus of carceral oppression (Meiners \& Winn, 2014. p. 4, italics in original); in short, it offers some possibilities to cultivate social life rather than social death.

The perpetrators of suffering for the six participants were both the school system, including teachers, staff, and school police, and the justice system, including police and, to a lesser extent, the courts. As an educator, I feel most equipped to offer suggestions for teachers. A key first step in cultivating social life of Black and Latino boys is for teachers to expand their view beyond the confines of the school to see the ways schools and the juvenile justice system both reflect and perpetuate larger forces of oppression that criminalize and dehumanize young people. It is not enough, however, for schools to merely acknowledge their role in the larger system of social death, knowledge must be followed by action. From systemic change to 
change in the classroom, school systems and the educators who work in them have the agency to disrupt the nexus of carceral oppression.

In schools with punitive policies, schools have the ability and obligation to reflect on the ways they may perpetuate or be complicit in the criminalization and dehumanization of their students. In the most optimistic scenario, educators would dedicate themselves fighting the oppressive and interlocking systems of school and prison by dismantling the policies and laws at the state and local level that codify social death. One way to do this is at the state level is repeal the STEP Act. An example of change at the district level happened over the summer of 2020 in Oakland, California, when youth organizers and their allies succeeded in eliminating the school police department (Oakland Unified School District, 2020) and reinvesting the police budget into school mental health and restorative justice services (Getachew, 2021).

Even educators whose goal is not carceral abolition can still incorporate tenets of abolition to enact change. One example of this is to incorporate aspects of transformative justice in addressing harm. In contrast to the criminalization of Black and Brown youth, transformative justice focuses on addressing the systemic harms of White supremacy, economic racism, and other forms of oppression that cause suffering for youth of color. In contrast to the dehumanization of Black and Brown youth, transformative justice holds an individual who causes harm accountable for their behavior, "without disregarding their humanity" and by contextualizing the reasons someone might enact harm, for example, by "[u]understanding that harm originates from situations dominated by stress, scarcity, and oppression" (Kaba, 2021, p. 59), and then addressing those root causes rather than punishing the outcome.

While simultaneously fighting for systemic change, educators can also impact the day-to-day lives of students by incorporating way to help youth develop the tools to heal from and disrupt forces of social death inside and outside of the classroom. Ginwright (2015) lays out a plan for helping Black youth heal through education summarized through the acronym C.A.R.M.A. (Culture, Agency, Relationships, Meaning, Achievement). Developing curriculum that helps youth discover their purpose (meaning), supports their individual and collective ability to enact transformative change (Agency), and working together to attain individual and collective goals (Achievement and Relationships). C.A.R.M.A. can be adapted to support other oppressed groups. For example, teaching both Black and Latino boys, like the six participants, about the intersections of race and gender, including the positive contributions, historical oppressions, and ways of healing, can help them develop a deeper, more grounded cultural understanding of themselves (Culture).

Even educators unable or not yet willing to undertake changes at the structural or the curriculum level, can still help mitigate the suffering of social death. For example, when asked if he had any closing words, Wally, whose analysis opened this paper, suggested a practical starting point for counteracting the dehumanization aspect of social death. He wanted to say the following directly to anyone who would be listening to his interview. To all of you he says: 
People just need to see the light. That's really all it is. Start uplifting folks, just tell folks that they're going to be good at what they're doing, no matter what they're doing. Just tell them that they're going to do good.

\section{Declarations}

Conflict of interest On behalf of all authors, the corresponding author states that there is no conflict of interest.

Open Access This article is licensed under a Creative Commons Attribution 4.0 International License, which permits use, sharing, adaptation, distribution and reproduction in any medium or format, as long as you give appropriate credit to the original author(s) and the source, provide a link to the Creative Commons licence, and indicate if changes were made. The images or other third party material in this article are included in the article's Creative Commons licence, unless indicated otherwise in a credit line to the material. If material is not included in the article's Creative Commons licence and your intended use is not permitted by statutory regulation or exceeds the permitted use, you will need to obtain permission directly from the copyright holder. To view a copy of this licence, visit http://creativecommons.org/licen ses/by/4.0/.

\section{References}

$\S$ 17235. "Switchblade knife", Cal Pen Code $§$ 17235. Retrieved 10/27/19 from https://advance-lexiscom.libproxy.berkeley.edu/api/document?collection=statutes-legislation\&id=urn:contentItem: 5JFB-0WV1-DYB7-W36H-00000-00\&context=1516831

$\S$ 594. Vandalism; Punishment, Cal Pen Code $§ 594$ https://advance-lexis-com.libproxy.berkeley.edu/api/ document?collection $=$ statutes-legislation\&id=urn:contentItem:5JFB-0P11-DYB7-W44G-00000$00 \&$ context $=1516831$

$\S$ 21510. Switchblade knife; Punishment, Cal Pen Code $§ 21510$. Retrieved 10/27/19 from https://advan ce-lexis-com.libproxy.berkeley.edu/api/document?collection=statutes-legislation\&id=urn:conte ntItem:5JFB-0WV1-DYB7-W3DK-00000-00\&context=1516831

$\S 640.5$. Affixing graffiti on or in vehicles of governmental entity or public transportation system, Cal Pen Code $\S 640.5$ https://advance-lexis-com.libproxy.berkeley.edu/api/document?collection=statu tes-legislation\&id=urn:contentItem:5JFB-0P11-DYB7-W4HW-00000-00\&context $=1516831$

$\S$ 794. Conditions of probation, Cal Wel \& Inst Code $\S 794$. Retrieved 10/27/19 from https://advancelexis-com.libproxy.berkeley.edu/api/document?collection=statutes-legislation\&id=urn:contentItem: 5JX4-9V81-66B9-80CC-00000-00\&context $=1516831$

Alvarez, L., \& Buckley, C. (2012). Zimmerman is Acquitted in Trayvon Martin Killing. New York Times. July 13, 2013. Retrieved on September 19, 2021 from https://www.nytimes.com/2013/07/14/us/ george-zimmerman-verdict-trayvon-martin.html

Anderson, E. (2012). The iconic ghetto. The ANNALS of the American Academy of Political and Social Science, 642(1), 8-24.

Archer, D. N. (2009). Introduction: Challenging the school-to-prison pipeline. The New York Law School Law Review, 54, 867-872.

Benekos, P. J., \& Merlo, A. V. (2014). Controversies in juvenile justice and delinquency. Routledge.

Bloch, S. (2020). Broken windows ideology and the (mis) reading of graffiti. Critical Criminology, 28, $703-720$.

Cacho, L. M. (2012). Social death: Racialized rightlessness and the criminalization of the unprotected. NYU Press. 
Chapter 11. Street Terrorism Enforcement and Prevention Act, Cal Pen Code Pt. 1, Title 7, Ch. 11. https://advance-lexis-com.libproxy.berkeley.edu/api/document?collection=statutes-legislation\&id= urn:contentItem:5JFB-0P11-DYB7-W2S1-00000-00\&context=1516831

Charmaz, K. (1996). The search for meanings-grounded theory. In J. A. Smith, R. Harre, \& L. Van Langenhove (Eds.), Rethinking methods in psychology (pp. 27-49). SAGE Publications.

Corbin, J. M., \& Strauss, A. (1990). Grounded theory research: Procedures, canons, and evaluative criteria. Qualitative Sociology, 13(1), 3-21. https://doi.org/10.1007/BF00988593

Davis, K. (2015). School house gates: Please remove your rights. Willamette Law Review, 52, 353-371.

Dutton, P. (1984). Justifying school searches: The problems with the doctrine of in loco parentis. J. Juv. L., 8, 140-148.

Estevane, G. (2105). In defense of a gang member Sample gang witness expert report. In June, D. L., Khatibloo, M., \& Estevane, G. (Eds.), The Re-evolution of American street gangs. CRC Press (pp. 218-233).

Falzone, G. (2020). Faces of Death: Towards the Sociogeny of Adolescent Incarceration (Doctoral dissertation, UC Berkeley).

Farmer, S. (2014). Criminality of Black youth in inner-city schools: 'moral panic', moral imagination, and moral formation. In Meiners \& Winn (Eds.), Education and incarceration. Routledge.

Fasching-Varner, K. J., Mitchell, R. W., Martin, L. L., \& Bennett-Haron, K. P. (2014). Beyond school-toprison pipeline and toward an educational and penal realism. Equity and Excellence in Education, 47(4), 410-429.

Ferguson, A. A. (2000). Bad boys: Public schools in the making of black masculinity. University of Michigan Press.

Fine, M., Freudenberg, N., Payne, Y., Perkins, T., Smith, K., \& Wanzer, K. (2003). "Anything can happen with police around": Urban youth evaluate strategies of surveillance in public places. Journal of Social Issues, 59(1), 141-158.

Getachew, S. (2021). Oakland eliminated its school police force-So what happens now? March 11, 2021. Retrieved May 16, 2021 from https://www.kqed.org/arts/13893831/oakland-eliminated-itsschool-police-force-so-what-happens-now

Ginwright, S. (2015). Hope and healing in urban education: How urban activists and teachers are reclaiming matters of the heart. Routledge.

Goff, P. A., Jackson, M. C., Leone, D., Lewis, B. A., Culotta, C. M., \& DiTomasso, N. A. (2014). The essence of innocence: Consequences of dehumanizing Black children. Journal of Personality and Social Psychology, 106(4), 526.

Gonzalez, J. C., \& Portillos, E. L. (2007). The undereducation and overcriminalization of US Latinas/os: A post-Los Angeles riots LatCrit analysis. Educational Studies, 42(3), 247-266.

Gottfredson, D. C. (2001). Schools and delinquency. Cambridge University Press.

Guenther, L. (2013). Solitary confinement: Social death and its afterlives. University of Minnesota Press.

Gupta-Kagan, J. (2018). Reevaluating school searches following school-to-prison pipeline reforms. Fordham Law Review, 87, 2013-2068.

Haslam, N., \& Loughnan, S. (2014). Dehumanization and infrahumanization. Annual Review of Psychology, 65, 399-423.

Heitzeg, N. A. (2009). Education or incarceration: Zero tolerance policies and the school to prison pipeline. In Forum on public policy online (Vol. 2009, No. 2). Oxford Round Table. Urbana

Jones, N. (2014). "The regular routine": Proactive policing and adolescent development among young, poor black men. New Directions for Child and Adolescent Development, 2014(143), 33-54.

Kaba, M., Murakawa, N., \& In Nopper, T. K. (2021). We do this 'til we free us: Abolitionist organizing and transforming justice.

King, S., Rusoja, A., \& Peguero, A. A. (2018). The school-to-prison pipeline. In J. Deakin, E. Taylor, \& A. Kupchik (Eds.), the Palgrave international handbook of school discipline, surveillance, and social control (pp. 269-290). Palgrave Macmillan.

Krisberg, B., \& Austin, J. F. (1993). Reinventing juvenile justice. Sage.

Kupchik, A. (2010). Homeroom security: School discipline in an age of fear. NYU Press.

Males, M. (2014). Who are the Police Killing? Center on Juvenile and Criminal Justice. Published online August 26, 2014. Accessed on October 22, 2019 from http://www.cjcj.org/news/8113

Mallett, C. A. (2017). The school-to-prison pipeline: Disproportionate impact on vulnerable children and adolescents. Education and Urban Society, 49(6), 563-592. 
Mann, H. (1848). Twelfth annual report to the Massachusetts Board of Education. The republic and the school: Horace Mann and the education of free men.

McGrew, K. (2016). The dangers of pipeline thinking: How the school-to-prison pipeline metaphor squeezes out complexity. Educational Theory, 66(3), 341-367.

Meiners, E. R. (2007). Right to be hostile: Schools, prisons, and the making of public enemies. Routledge.

Meiners, E. R., \& Winn, M. T. (2014). Education and incarceration. Routledge.

Merlo, A. V., \& Benekos, P. J. (2017). Chapter 2: Demonization of youth and politicization of juvenile justice, In Reaffirming juvenile justice: From gault to montgomery (pp. 22-39). Routledge.

National Academies of Sciences, Engineering, and Medicine. (2018). Proactive policing: Effects on crime and communities. National Academies Press.

Noguera, P. A. (2003). The trouble with Black boys: The role and influence of environmental and cultural factors on the academic performance of African American males. Urban Education, 38(4), 431-459.

Oakland Unified School District (2020) George Floyd Resolution No. 1920-0260. Accessed on 18 May, 2021 from https://assets.documentcloud.org/documents/6956560/OUSD-Elimination-Departmentof-Police-Services.pdf

Patterson, O. (1982). Slavery and social death. Cambridge, Harvard University.

Platt, A. M. (1977). The child savers: The invention of delinquency. University of Chicago Press.

Price, J. M. (2015). Prison and social death. Rutgers University Press.

Rios, V. M. (2011). Punished: Policing the lives of Black and Latino boys. NYU Press.

Rios, V. M., \& Galicia, M. G. (2014). Smoking guns or smoke and mirrors?: Schools and the policing of Latino boys. Association of Mexican American Educators Journal, 7(3), 54-66.

Rios, V. M., \& Vigil, J. D. (2017). Human targets: Schools, police, and the criminalization of Latino youth. University of Chicago Press.

Rovner, J. (2016). Racial Disparities in Youth Commitments and Arrests, The Sentencing Project. Retrieved 14, November, 2019 from https://www.sentencingproject.org/publications/racial-dispa rities-in-youth-commitments-and-arrests/

Scott, E. S., \& Steinberg, L. (2008). Adolescent development and the regulation of youth crime. The Future of Children, 18(2), 15-33.

Sexton, J. (2010). People-of-color-blindness notes on the afterlife of slavery. Social Text, 28(2(103)), 31-56.

Sexton, J. (2016). Chapter 3: The social life of social death: On Afro-pessimism and Black optimism. In A. M. Agathangelou \& K. D. Killian (Eds.), Time, temporality and violence in international relations:(De) fatalizing the present, forging radical alternatives (pp. 85-99). Routledge.

Shedd, C. (2015). Unequal city: Race, schools, and perceptions of injustice. Russell Sage Foundation.

Skiba, R. J., Arredondo, M. I., \& Williams, N. T. (2014). More than a metaphor: The contribution of exclusionary discipline to a school-to-prison pipeline. Equity and Excellence in Education, 47(4), 546-564.

Sojoyner, D. M. (2013). Black radicals make for bad citizens: Undoing the myth of the school to prison pipeline. Berkeley Review of Education, 4(2), 241-263.

Sojoyner, D. M. (2016). First strike: Educational enclosures in black Los Angeles. University of Minnesota Press.

Sowle, S. D. (1993). A regime of social death: Criminal punishment in the age of prisons. NYU Review of Law and Social Change, 21, 497-566.

Story, B. (2016). The prison in the city: Tracking the neoliberal life of the "million dollar block." Theoretical Criminology, 20(3), 257-276.

Strauss, A., \& Corbin, J. (1998). Basics of Qualitative Research: Techniques and Procedures for Developing Grounded Theory, Chapters 8 and 9. Sage: Thousand Oaks, London.

The Sentencing Project (2017) Fact Sheet: Latino Disparities in Youth Incarceration. Retrieved from 14 November, 2019 https://www.sentencingproject.org/publications/latino-disparities-youth-incarcerat ion/

Vaught, S. E. (2017). Compulsory: Education and the dispossession of youth in a prison school. London: University of Minnesota Press.

Wacquant, L. (2001). Deadly symbiosis: When ghetto and prison meet and mesh. Punishment and Society, 3(1), 95-133. 
Wald, J., \& Losen, D. J. (2003). Defining and redirecting a school-to-prison pipeline. New Directions for Youth Development, 2003(99), 9-15.

Weinstein, A., \& the MoJo Team (2012). The Trayvon Martin Killing, Explained. Mother Jones. March 18, 2012. Accessed 19 September, 2021 from https://www.motherjones.com/politics/2012/03/whathappened-trayvon-martin-explained/

Wun, C. (2016). Against captivity: Black girls and school discipline policies in the afterlife of slavery. Educational Policy, 30(1), 171-196.

Publisher's Note Springer Nature remains neutral with regard to jurisdictional claims in published maps and institutional affiliations. 